\title{
RENEWABLE RESOURCE INTEGRATION PROJECT- SCOPING STUDY OF STRATEGIC TRANSMISSION, OPERATIONS, AND RELIABILITY ISSUES
}

Prepared For:

California Energy Commission

Public Interest Energy Research Program

Prepared By:

Consortium for Electric Reliability

Technology Solutions/Electric Power Group

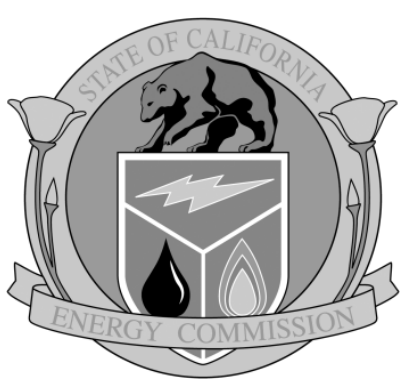

Arnold Schwarzenegger Governor 

Prepared By:

Electric Power Group

Vikram Budhraja, John Ballance, Jim Dyer, Fred Mobasheri

Pasadena, California 91101

Joseph Eto

Lawrence Berkeley National Laboratory

Berkeley, California 94720

Commission Contract No. 500-02-004

Commission Work Authorization No. MRA-047

Prepared For:

Public Interest Energy Research (PIER)

California Energy Commission

Clare Laufenberg Gallardo

Contract Manager

Gerald Braun

Program Area Lead

Insert: Program Area Name

Ken Koyama

Office Manager

Energy Generation Research Office

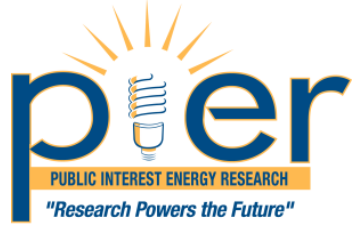

Martha Krebs, Ph.D.

PIER Director

Thom Kelly, Ph.D.

Deputy Director

ENERGY RESEARCH \& DEVELOPMENT DIVISION

Melissa Jones

Executive Director

\section{DISCLAIMER}

This report was prepared as the result of work sponsored by the California Energy Commission. It does not necessarily represent the views of the Energy Commission, its employees or the State of California. The Energy Commission, the State of California, its employees, contractors and subcontractors make no warrant, express or implied, and assume no legal liability for the information in this report; nor does any party represent that the uses of this information will not infringe upon privately owned rights. This report has not been approved or disapproved by the California Energy Commission nor has the California Energy Commission passed upon the accuracy or adequacy of the information in this report. 



\section{ACKNOWLEDGMENTS}

The research team wishes to thank Clare Laufenberg Gallardo and Don

Kondoleon, Project Managers for their guidance, support, and encouragement throughout the project. 


\section{Preface}

The Public Interest Energy Research (PIER) Program supports public interest energy research and development that will help improve the quality of life in California by bringing environmentally safe, affordable, and reliable energy services and products to the marketplace.

The PIER Program, managed by the California Energy Commission (Energy Commission), conducts public interest research, development, and demonstration (RD\&D) projects to benefit California.

The PIER Program strives to conduct the most promising public interest energy research by partnering with RD\&D entities, including individuals, businesses, utilities, and public or private research institutions.

PIER funding efforts are focused on the following RD\&D program areas:

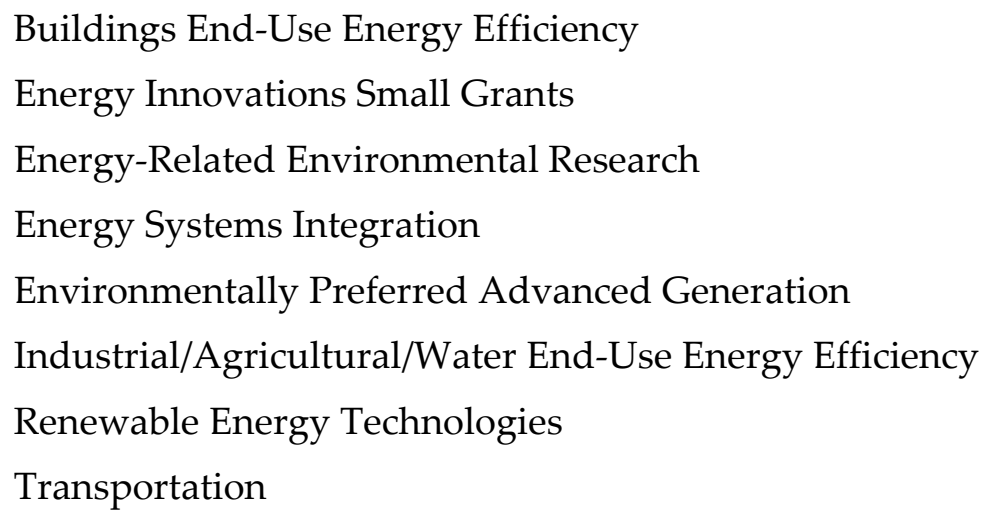

Renewable Resource Integration Project-Research Study of Strategic Transmission, Operations, and Reliability Issues Report for the PIER project (contract number 500-02-004, work authorization number MRA-047) conducted by Consortium for Electric Reliability Technology Solutions. The information from this project contributes to PIER's Energy-Related Environmental Research Program.

For more information about the PIER Program, please visit the Energy Commission's website at www.energy.ca.gov/pier or contact the Energy Commission at 916-654-5164.

Please cite this report as follows:

Budhraja, Vikram, John Ballance, Jim Dyer, and Fred Mobasheri (Electric Power Group, LLC), Eto, Joseph (Lawrence Berkeley National Laboratory). Renewable Resource Integration ProjectScoping Study of Strategic Transmission, Operations, and Reliability Issues, PIER Final Project Report. California Energy Commission, PIER Energy-Related Environmental Research Program. Publication \#500-2008-XXX. 


\section{Table of Contents}

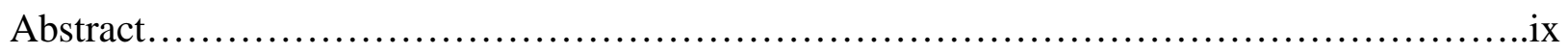

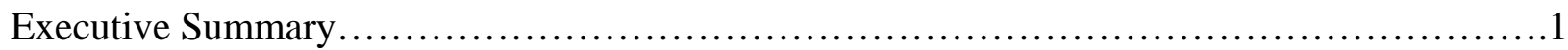

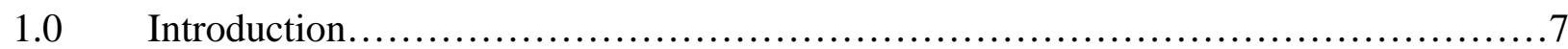

1.1. Research Objective

$2.0 \quad$ Project Approach................................................................

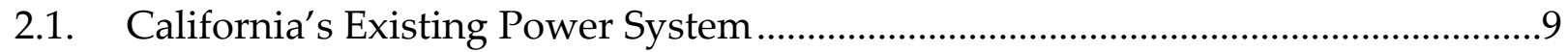

2.2. Estimates of Potential Renewable Resources ......................................................10

2.3. Renewables Integration-Expanding the Existing Transmission Gateway Limits10

2.4. Expanding the Transmission Grids in the Major Load Centers ...............................10

Project Results.....................................................................

3.1. Power System Operations and Reliability ……………............................................11

3.2. Renewables Resource Integration and Operation ...................................................11

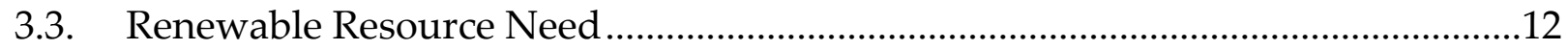

3.4. Renewables Development-Location and Resource Type.......................................14

3.5. Transmission Gateways Around Load Centers and Capacity for New Renewables to be Delivered to Load Centers............................................................16

3.6. Transmission Gateways Serving the Los Angeles Basin Area Served by the

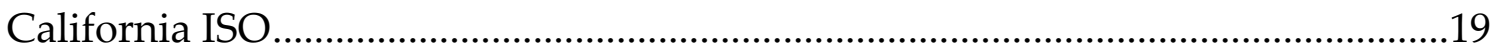

3.7. Transmission Gateway Capacity -Current Plans and Future Needs ...................20

3.8. Transmission Expansion Required within Local Load Areas...................................21

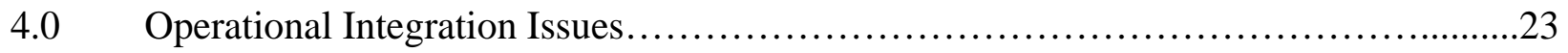

4.1. Issues to Be Considered for Renewable Resource Integration.................................23

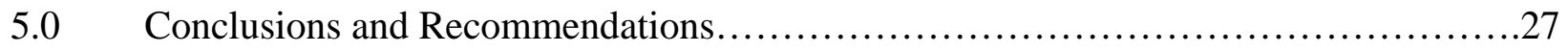


5.1.1. California's renewable resource needs and locations ...................................... 27

5.1.2. Transmission gateways and access to load centers.......................................... 27

5.1.3. Integration of remote non-renewable resources............................................ 27

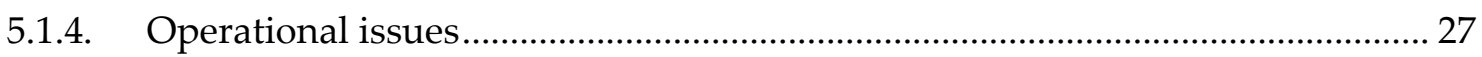

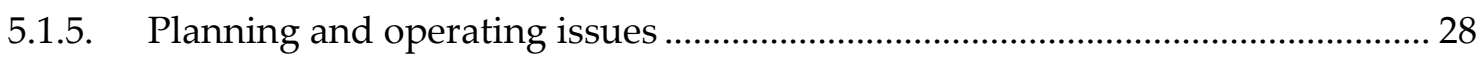

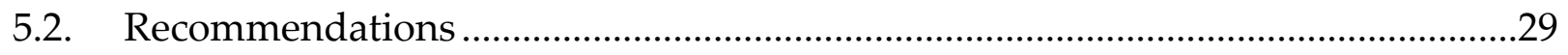

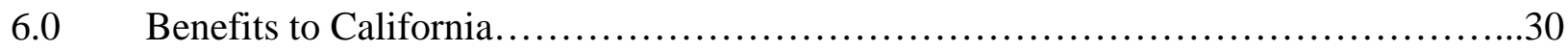

7.0 References.................................................................

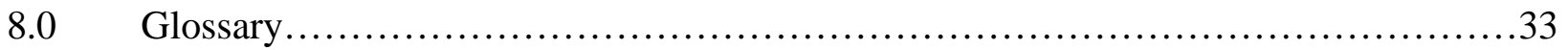

\section{List of Tables}

Table 1. Transmission Gateways to California’s Major Load Centers - Illustrative List ...............9

Table 2. Peak Demand and Energy Consumption Forecast......................................................12

Table 3. Renewable Energy Production Required for Alternative RPS Goals...........................12

Table 4. Renewable Energy and Capacity_2006 Recorded, 2020 Estimated for 33\% RPS ........13

Table 5. 2006 Renewable Capacity and Estimated Requirements in 2020 and 2030 (MW)........13

Table 6. 2006 Renewable Energy \& Estimated Requirements in 2020 and 2030 (Billion kWH) 14

Table 7. Resource additions and current installed capacity of renewable resources...................16

Table 8. Hypothetical Amount (MW) and Location of Future Renewable Resources..................16

Table 9. Peak Load Areas Identified in California ISO Study ..............................................17

Table 10. Load Areas and Transmission Import Limits .......................................................18

Table 11. Los Angeles Transmission Gateways for Integrating 20,000 MW of New Renewable

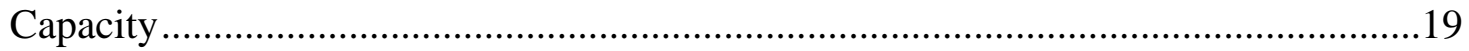

Table 12. Qualitative Assessment of Resource Options on Renewables Integration...................28

Table 13. Qualitative Assessment of Issues and Action Items for Renewables Integration.........28 


\section{List of Figures}

Figure 1. L.A. Basin Area Transmission Gateways ....................................................................... 20 


\begin{abstract}
California is on a path to increase utilization of renewable resources. California will need to integrate approximately 30,000 megawatts (MW) of new renewable generation in the next 20 years.
\end{abstract}

Renewable resources are typically located in remote locations, not near the load centers. Nearly two-thirds or 20,000 MW of new renewable resources needed are likely to be delivered to Los Angeles Basin transmission gateways. Integration of renewable resources requires interconnection to the power grid, expansion of the transmission system capability between the backbone power grid and transmission gateways, and increase in delivery capacity from transmission gateways to the local load centers.

To scope the transmission, operations, and reliability issues for renewables integration, this research focused on the Los Angeles Basin Area transmission gateways where most of new renewables are likely. Necessary actions for successful renewables integration include:

1. Expand Los Angeles Basin Area transmission gateway and nomogram limits by 10,000 to $20,000 \mathrm{MW}$.

2. Upgrade local transmission network for deliverability to load centers.

3. Secure additional storage, demand management, automatic load control, dynamic pricing, and other resources that meet regulation and ramping needed in real time operations.

4. Enhance local voltage support.

5. Expand deliverability from Los Angeles to San Diego and Northern California.

\title{
Keywords:
}

California transmission grid, Renewable Energy Transmission Initiative (RETI), Public Interest Energy Research (PIER) Program, Renewables deployment, Renewable Portfolio Standard (RPS), Resource attributes, Scenario analysis, Transmission expansion, Transmission gateways 


\section{Executive Summary}

\section{Introduction}

California is on a path to increase utilization of renewable resources to provide for growing electricity needs and meet greenhouse gas (GHG) reduction targets. The use of additional renewable resources is in response to several legislative and policy directives. Renewable resources are likely to be located remote from load centers and issues related to transmission, operations, and reliability need to be addressed to integrate new renewable resources.

\section{Purpose}

The objective of this Renewable Resource Integration Project was to conduct a scoping research assessment of strategic transmission, operations, and reliability issues to meet California's goals in light of emerging regulatory and policy directives, and current electric industry activities such as the Renewable Energy Transmission Initiative (RETI).

\section{Project Objectives and Outcomes}

The project objective is to understand the many issues that need to be addressed to assure timely development and integration of renewables. Several initiatives are underway that have a bearing on integration of renewables, the most notable of which is California's RETI.

In this project, renewable resource needs under different scenarios were estimated. In order to meet California's goals for expanded use of renewable resources, California must develop and integrate approximately 30,000 megawatts (MW) of new renewable generation in the next 20 years. Renewable generation needs to be located where renewable resources are plentiful. Large-scale development of wind, solar thermal, and geothermal resources will typically be remote from the load centers.

Renewables resources have to be interconnected to the power grid for eventual delivery of power to the load centers. In addition to constructing effective transmission interconnections between the renewable resource development areas and California's high-voltage electrical grid, it will be necessary to expand the transmission system capability between the backbone grid and transmission gateways and from transmission gateways to the local load centers.

The power resources located within the transmission gateways (referred to as local generation) govern the amount of power that can be imported into the load centers from outside the transmission gateways. A primary criterion is to have adequate transmission and generation to withstand the loss of the largest generating unit plus the next most significant element (generator or transmission line) without overloads or cascading outages. Transmission studies define import limits over single transmission paths and nomograms define limits for combined imports over several transmission paths. The local generation is used to assure voltage adequacy, inertia and operation within safe operating limits. 
The Renewable Portfolio Standard (RPS) goal is for 20 percent of energy consumption to be supplied from renewables by 2010, with a target of 33 percent to be supplied by 2020. Assembly Bill 32 (AB 32) targets are likely to move California towards greater contributions from renewables. Assuming that goals of 33 percent RPS by 2020 and 50 percent RPS by 2030 must be met, the research showed that starting from a 2006 base:

- Renewable capacity additions of 20,000 MW will be needed by 2020 and 40,000 MW will be needed by 2030 .

- By the year 2030, renewable resource additions of 23,000 MW will be needed for 33 percent Renewable Portfolio Standard goal and 40,000 MW for 50 percent RPS goal. For this scoping study, a mid-range estimate of $30,000 \mathrm{MW}$ is assumed to be needed over the next 20-years.

- To achieve the 33 percent RPS by 2020, energy production from renewable resources will displace energy presently produced by non-renewable generation. Non-renewable generation will produce 13 percent less energy than in 2008.

- Intermittent wind energy will contribute about 10 percent of total energy requirements in 2020 and nearly 20 percent in 2030.

To meet the need for 30,000 MW of new renewable capacity and scope renewable resource integration issues, development of new renewables is assumed to take place as follows:

- Geothermal-3,500 MW total, with 2,000 MW in the Imperial Valley, $400 \mathrm{MW}$ in Northern California, $100 \mathrm{MW}$ in Randsburg (South of China Lake, California), and 1,000 MW in Northern Nevada.

- Biomass-1,500 MW distributed within or near load centers.

- Wind-16,000 MW total, with 6,000 MW in Tehachapi, 2,000 MW in the Imperial Valley, 2,000 MW in San Gorgonio, 2,000 MW in Northern California, 2,000 MW from the Pacific Northwest, and 2,000 MW from Nevada-Arizona.

- Solar Photovoltaic-2,000 MW distributed within load centers.

- Solar Thermal-7,000 MW total, with 2,500 MW at Mohave, 3,000 MW at Barstow, and 1,500 MW in Central and Northern California.

This distribution was derived based on a review of assessments made by RETI, Energy Commission studies, and other readily available information relating to renewables location. The distribution of renewables is one possible scenario that was used for scoping of issues and not meant to be definitive.

Based on the geographic distribution of projected new renewable development, more than twothirds of the new renewable resources would likely have to be delivered to Los Angeles (L.A.) Basin Area transmission gateways (as defined by the California Independent System Operator (California ISO) 2009 Local Capacity Technical Analysis 1 - . This means that nearly 20,000 MW of

\footnotetext{
${ }^{1}$ California Independent System Operator. May 1, 2008. 2009 Local Capacity Technical Analysis - Final Report and Study Results, [http://www.caiso.com/1fba/1fbace9b2d170.pdf]
} 
new renewable capacity will have to be integrated into the California electric grid via the L.A. Basin Area transmission gateways. Hence, for this scoping study, the L.A. Basin Area was analyzed to assess issues that need to be considered for renewable resource integration. While the L.A. Basin Area was selected for the purposes of this scoping study, similar transmission gateway delivery issues can be expected in the other load areas as the reliance on remote renewable generation is increased to meet the RPS goals.

Based on the California Independent System Operator (California ISO) 2009 Local Capacity Technical Analysis ${ }^{2}$ results, also referred to as Local Capacity Requirements (LCR) studies, there are five local areas which comprise over 5 percent of the total load. These five areas in total account for approximately 87 percent of the total load. The five areas are:

1. Greater Bay Area.

2. Greater Fresno Area.

3. L.A. Basin Area.

4. Big Creek/Ventura Area.

5. San Diego Area.

For each of the locally constrained resource areas, the transmission lines which form the study boundary and the gateway substations that bound each local area are identified. Based on the line ratings that bound each area, a total import capability can be determined for each of the load areas. The 2009 Local Capacity Technical Analysis describes the simultaneous import limits across the local area boundary transmission lines, which limit also affects the requirement for local generation. The aggregate import limits of the transmission gateways into each of the local areas are also presented in the California ISO 2009 Local Capacity Technical Analysis. For the L.A. Basin Area served by the California ISO, the aggregated rated capacity of all the transmission gateways is over 23,000 MW but the aggregated import limit is less than half or 10,642 MW.

\section{Conclusions}

If two-thirds of the new renewable resources are likely be delivered to L.A. Basin Area transmission gateways nearly 20,000 MW of new renewable capacity would have to be integrated via the L.A. Basin Area gateways. Based on forecasts of renewable resource locations, the future transmission needs (beyond Tehachapi and Devers-Palo Verde 2) are as follows:

\footnotetext{
${ }^{2}$ California Independent System Operator. May 1, 2008. 2009 Local Capacity Technical Analysis - Final Report and Study Results, [http://www.caiso.com/1fba/1fbace9b2d170.pdf], [http://www.caiso.com/1fba/1fbace9b2d170.pdf].
} 


\begin{tabular}{|c|l|l|}
\hline$\frac{\text { Additional MW of }}{\text { Capacity }}$ & Location & Resource Type \\
\hline 1,500 & Vincent/Antelope Gateway & Wind \\
\hline 4,000 & Mirage Gateway & Geothermal and Wind \\
\hline $5,500-7,500$ & Lugo Gateway & $\begin{array}{l}\text { Solar thermal and Nevada- } \\
\text { Arizona Wind }\end{array}$ \\
\hline $2,000-4,000$ & Devers Transmission Gateway & Wind \\
\hline
\end{tabular}

Currently, the California ISO experiences many operational issues such as regulation, ramping, voltage support, with the existing resource portfolio in its control area, and these issues will likely worsen with addition of remote renewables and shutdown of local generation due to air quality and water use constraints unless steps are taken to resolve or mitigate the issues. Most of the issues relate to resource and demand balancing within the control area. Besides the fact that the operational issues can be extremely challenging for the control area operator to manage, the failure to comply with a North American Electric Reliability Corporation (NERC) Performance Standards could lead to a $\$ 1$ million/per day penalty.

An assessment of the L.A. Basin Area was made to scope the renewable resource integration issues. The following table provides a qualitative assessment of issues and the necessary action items to effectively integrate renewables and ensure reliable power system operations.

\begin{tabular}{|l|c|}
\hline \multicolumn{1}{|c|}{ Issues } & Action Items \\
\hline Add New Renewables & Addition of 20,000 MW of Renewables - Base Case \\
\hline $\begin{array}{l}\text { Transmission Gateway } \\
\text { Capacity }\end{array}$ & $\begin{array}{c}\text { Expand by 10,000 to 20,000 MW } \\
5-15 \text { year lead time }\end{array}$ \\
\hline $\begin{array}{l}\text { Local Network } \\
\text { Reinforcements }\end{array}$ & Upgrade lines, fault current limiters, breakers, remedial action schemes \\
\hline $\begin{array}{l}\text { Nomogram Capacity } \\
\text { Import Limits }\end{array}$ & Expand by 10,000 to 20,000 MW \\
\hline $\begin{array}{l}\text { Regulation and } \\
\text { Ramping }\end{array}$ & Need additional Regulation \& Ramping \\
\hline Local Voltage Support & Add capacitors and dynamic voltage control devices \\
\hline
\end{tabular}

\section{Recommendations}

Meeting California's RPS on a timely basis requires a concerted effort on several fronts:

a. The planning and study focus needs to immediately expand from evaluating just the interconnection of remote renewable resources to the grid to one of delivering the renewable energy all the way to the respective load centers. 
b. Policy makers need to provide guidance on resource type and location to facilitate timely integration of renewables, and support early planning and upgrades of transmission gateway capacity and deliverability to load centers. This effort will be aided by the RETI effort currently underway.

c. Transmission owners and California ISO need to move the planning horizon out to 1520 years.

o Define long-term transmission gateway requirements.

o Define long-term transmission requirements from the gateways into the load centers.

d. Transmission owners and the California ISO need to initiate studies (similar to those conducted for Tehachapi) to expand transmission gateways and deliverability into the load centers.

e. Provide policy makers with information associated with the complete transmission integration requirement and cost implications for delivering all remote resource (renewable and non-renewable) to the local load centers.

f. California ISO needs to provide utilities and CPUC with guidance on resource attributes needed for reliable operation of the power system.

g. Transmission requirements for transfer of larger amounts of renewable energy from the L.A. Basin to San Diego and Northern California need to be reviewed and upgrades planned.

\section{Benefits to California}

Carrying out the recommendations from this initial scoping research study will facilitate integration of renewables to meet California's goals for greater utilization of renewable resources and meeting the Renewable Portfolio Standard. 


\subsection{Introduction}

California is on a path to increase utilization of renewable resources to provide for growing electricity needs, to attain fuel diversity for power production, and meet GHG reduction targets. The use of additional renewable resources is in response to the following legislative and policy directives:

- 2002-Senate Bill (SB) 1078 (Sher, Chapter 516, Statutes of 2002) established a statewide Renewable Portfolio Standard (RPS) of $20 \%$ by 2017.

- 2005-California Public Utilities Commission (CPUC) and California Energy Commission (Energy Commission) adopted the Energy Action Plan II that called for renewable resources to provide 33\% of California's electricity by 2020.

- 2006-SB 107 (Simitian, Chapter 464, Statutes of 2006) accelerated the 20\% RPS target date to 2010 .

- 2007-AB 32 (Nuñez, Chapter 488, Statutes of 2006) targets greenhouse gas reduction, which is likely to require further reliance on renewable resources.

- US Clean Water Act Section 316(b) - requires the United States Environmental Protection Agency (U.S. EPA) to ensure that the location, design, construction and capacity of cooling water intake structures reflect the best technology available for minimizing adverse environmental impacts. Actions that will restrict the operation of the existing coastal generating plants are likely to require further reliance on renewable resources.

There are many issues that need to be addressed to assure timely development and integration of renewable resources. Several initiatives are underway that have a bearing on integration of renewables, the most notable of which is California's RETI. ${ }^{3}$ RETI involves a broad cross section of stakeholders with the goal of identifying and assessing competitive renewable energy zones (CREZs). RETI's objective is to "identify those CREZs that can be developed in the most cost effective and environmentally benign manner." This will inform policy makers on resource development location and economics, procurement, transmission planning, transmission corridor designation and generation siting, as well as the California ISO's generation interconnection process.

\subsection{Research Objective}

The objective of the Renewable Resource Integration Project was to conduct a scoping research assessment of strategic transmission, operations, and reliability issues to meet California's goals in light of emerging regulatory and policy directives and current electric industry activities such as RETI. The approach and tasks carried out in the research are summarized below:

3. www.energy.ca.gov/reti/ 
a. Quantify the magnitude of renewable resources needed under different scenarios and time frames.

b. Summarize magnitude, type and location of renewable resources likely to be developed to meet California's needs, based on existing Energy Commission studies, RETI, and other data sources.

c. Outline transmission interconnection and deliverability requirements for renewables integration.

d. Summarize emerging trends that impact renewables integration, including operating limits on existing power plants resulting from once-through cooling and air emission rules.

e. Identify and scope issues that impact integration of renewables and how they could be addressed, including nomograms, and local voltage requirements. 


\subsection{Project Approach}

\subsection{California's Existing Power System}

California's existing power system evolved through integrated resource planning by vertically integrated utilities. Power plants were located near load centers or near sources of fuel. This resulted in gas and nuclear power plants near the major load clusters of San Francisco, L.A. County, Orange County, and San Diego. In addition, hydro power plants were built in the Sierras and out-of-state power (coal, nuclear, hydro) was delivered to the load centers via highvoltage transmission interconnections with neighboring states. For the most part, large hydro and pump storage projects and gas-fired generation near load centers provided the following operating attributes:

- Load following.

- Spinning and operating reserve.

- Regulation and ramping.

- Voltage support.

- Inertia.

- Local supply adequacy and reliability.

The transmission system was planned for delivery of local and imported power to loads. Imported power entered the load centers via major transmission gateways. These transmission gateways serve as the entry point for power to California major load centers and are generally 230 kilovolt $(\mathrm{kV})$ or $500 \mathrm{kV}$ substations with the capacity to integrate large amounts of electricity, typically over a thousand MWs. Most large-scale renewable resources will be developed outside of the local load centers served by the transmission gateways. Hence, it is important to understand the capacity at each gateway in order to facilitate the integration of renewables.

An illustrative listing of transmission gateways that serve California major load centers as defined by the California ISO in their studies of local load areas is shown in Table $1 .{ }^{4}$

Table 1. Transmission Gateways to California's Major Load Centers ${ }^{5}$ - Illustrative List

\begin{tabular}{|l|c|c|}
\hline $\begin{array}{c}\text { Major Load } \\
\text { Center }\end{array}$ & $\begin{array}{c}\text { Transmission Gateways - } \\
\text { Internal }\end{array}$ & Transmission Gateways - External \\
\hline San Francisco & Delta, Metcalf, Pittsburg & Moss Landing, Tesla, Vaca Dixon \\
\hline L.A. Basin & $\begin{array}{c}\text { Devers, Gould, Mesa, Mira } \\
\text { Loma, Rio Hondo, San Onofre }\end{array}$ & $\begin{array}{c}\text { Antelope, Lugo, Palo Verde, Sylmar, San Luis } \\
\text { Rey, Talega, Vincent }\end{array}$ \\
\hline San Diego & Miguel, San Luis Rey, Talega & Imperial Valley, San Onofre, Tijuana \\
\hline
\end{tabular}

Source: California ISO. 2009 Local Capacity Technical Analysis - Final Report and Study Results.

4. California Independent System Operator. May 1, 2008. 2009 Local Capacity Technical Analysis - Final Report and Results, [http://www.caiso.com/1fba/1fbace9b2d170.pdf],

5. Refers to areas served by the California ISO. 


\subsection{Estimates of Potential Renewable Resources}

In order to meet California's goals for expanded use of renewable resources, California must develop and integrate approximately 30,000 MWs of new renewable generation in the next 20 years. Because renewable generation depends upon natural resources for its energy supply, the resources will be developed where the natural resources are most favorable. This will mean that wind, solar thermal, and geothermal resources will be likely developed where their respective natural resources are most plentiful, which is typically not near the load centers. In contrast, biomass and solar photovoltaic may indeed be developed on a distributed basis near the load centers. Forecasts of renewable resource potential by region will be used to estimate a likely scenario of resource development.

\subsection{Renewables Integration-Expanding the Existing Transmission Gateway Limits}

Renewables resources have to be interconnected to the power grid for eventual delivery of power to the load centers. In addition to constructing effective transmission interconnections between the renewable resource development areas and California's high-voltage electrical grid, it will be necessary to expand the transmission system capability between the backbone grid transmission gateways and from the transmission gateways to the local load centers. Based on studies already performed by the California ISO, transmission gateways which will need to be expanded were identified. It is important for transmission owners to initiate studies to expand transmission gateways for integration of renewables so that transmission gateways do not become bottlenecks or constraints for timely integration of renewables to meet RPS goals.

\subsection{Expanding the Transmission Grids in the Major Load Centers}

Based on illustrative case studies performed for the Energy Commission, estimates of internal transmission upgrades that will also be required to accommodate the large expansion of the use of renewable resources are also discussed in this report. 


\subsection{Project Results}

\subsection{Power System Operations and Reliability}

The power resources located within the transmission gateways govern the amount of power that can be imported into the load centers from outside the transmission gateways. Reliability assessments are performed to evaluate the ability to maintain the integrity of the power system and keep the lights on under a variety of operating conditions, without overloading or damaging equipment. A primary criterion is to have adequate transmission and generation to withstand the loss of the largest single risk without overloads or cascading outages.

Transmission studies define import limits over single transmission paths and nomograms for combined imports over several transmission paths. For example, the Southern California Import Transmission (SCIT) nomogram establishes limits on what may be simultaneously imported into Southern California from several interconnections to the east, based on the portfolio of generation resources that are operating within the zone defined by transmission gateways or load centers. The local generation is used to assure voltage adequacy, inertia and operation within safe operating limits.

The development of renewable resources to meet California needs and policy goals, for the most part, will occur remote from the load centers. These renewable resources will need to deliver power to load centers through one or more of California's several transmission gateways. The quantity of renewables that could be integrated at each of the gateways is a function of adequate transmission from renewables to transmission gateways, capacity from gateways to load centers, the mix of resources within the load centers, and the network capacity within the load centers.

\subsection{Renewables Resource Integration and Operation}

There are several factors that impact integration of renewables into the power grid and operation of the power grid. These factors include:

- Amount of resources to be developed or resource need.

- Location of resources to be developed.

- Type of resources to be developed (defined by the operating characteristics of the resources, such as their daily energy production profiles).

- Interconnection of new renewables with the high voltage grid.

- New transmission or upgrades to move renewable power from the point of interconnection to transmission gateways.

- Upgrades required at and from each transmission gateway to expand deliverability capacity to load centers.

- Impact of likely changes to the current generation portfolio due to environmental constraints, retirements, and unit shutdowns, in particular of generation currently operating within the load centers. 


\subsection{Renewable Resource Need}

In November 2007, the Energy Commission provided the energy and capacity forecasts for 2008,2013 , and $2016 .{ }^{6}$ The forecasts expected energy consumption to increase at $1.29 \%$ annually until 2016, and the peak demand to increase at $1.37 \%$ annually until 2016. Forecast peak and energy for 2020 and 2030 were estimated by the Electric Power Group assuming the same growth rates, that is, $1.29 \%$ and $1.37 \%$, respectively, for energy and capacity, would continue until 2030. The resulting peak and energy forecasts are presented in Table 2.

Table 2. Peak Demand and Energy Consumption Forecast

\begin{tabular}{|l|c|c|c|c|c|}
\hline & $\mathbf{2 0 0 8}$ & $\mathbf{2 0 1 3}$ & $\mathbf{2 0 1 6}$ & $\mathbf{2 0 2 0}$ & $\mathbf{2 0 3 0}$ \\
\hline Peak Demand (MW) & 62,946 & 67,524 & 70,174 & 74,094 & 84,877 \\
\hline Energy (Billion kWH) & 289.0 & 309.1 & 320.2 & 337.0 & 383.1 \\
\hline
\end{tabular}

Source: California Energy Commission. California Energy Demand 2008 - 2018: Staff

Revised Forecast - Final Staff Report, 2nd Edition. Forecast values for 2020 and 2030 based on 2008-2016 forecast growth rates

The RPS goal is for $20 \%$ of energy consumption to be supplied from renewables by 2010, with a target of $33 \%$ to be supplied by 2020 . AB $32^{7}$ targets are likely to move California towards greater contributions from renewables. It is also likely that meeting the $20 \%$ RPS goal will be delayed by several years beyond the current deadline of 2010 . The amounts of renewable energy required to meet alternative levels of RPS by 2020 and 2030 are presented in Table 3.

Table 3. Renewable Energy Production Required for Alternative RPS Goals

\begin{tabular}{|c|c|c|c|c|}
\hline & $\begin{array}{c}\text { Total Annual Energy } \\
\text { Consumption }\end{array}$ & \multicolumn{4}{|c|}{ Renewable Energy Production B kWH } \\
\hline Year & In Billion kWH & 20\% RPS & 33\% RPS & 50\% RPS \\
\hline 2020 & 337 & 67 & 111 & 169 \\
\hline 2030 & 383 & 77 & 126 & 192 \\
\hline
\end{tabular}

Source: California Energy Demand 2008 - 2018: Staff Revised Forecast - Final Staff Report, 2nd Edition. Annual Energy Consumption from Table 2. Renewable Energy Production estimates calculated on 20\%, 33\% and 50\% of Annual Energy Consumption.

The Energy Commission estimated the total renewable capacity requirement to meet the 33\% RPS in 2020 as 26,622 MW. ${ }^{8}$ While there are many other scenarios and forecasts, for the purposes of this study, the Energy Commission report provides a good base line. The 2020 energy was estimated assuming 90\% capacity factor for geothermal and biomass, 30\% capacity factor for wind and solar, and the same production level from small hydro as recorded in 2006. This resulted in RPS energy production of 111 Billion kilowatt-hours (BkWh) in 2020, or 33\% of

6. California Energy Commission. 2007. California Energy Demand 2008 - 2018: Staff Revised Forecast - Final Staff Report, 2nd Edition. CEC-200-2007-015-SF2.

7. Chapter 488, Statutes of 2006. California Global Warming Solutions Act of 2006.

8. California Energy Commission. 2007. Integrated Energy Policy Report 2007-Commission Final Report, Publication Number CEC-100-2007-008-CMF. 
total energy. The recorded 2006 data and 2020 estimated amounts for 33\% RPS for energy and capacity are summarized in Table 4 . Hence, compared to 2006 recorded data, 20,301 MW of additional renewable capacity and $80.5 \mathrm{BkWh}$ of additional energy from renewables will be needed to meet the 33\% RPS target in 2020.

Table 4. Renewable Energy and Capacity-2006 Recorded, 2020 Estimated for 33\% RPS

\begin{tabular}{|l|c|c|c|c|c|c|}
\hline & \multicolumn{2}{|c|}{2006 Recorded In-State } & \multicolumn{2}{c|}{$\begin{array}{c}2020 \text { Estimates for 33\% } \\
\text { RPS }\end{array}$} & \multicolumn{2}{c|}{ Change } \\
\hline $\begin{array}{c}\text { Resource } \\
\text { Type }\end{array}$ & $\begin{array}{c}\text { Capacity } \\
\text { (MW) }\end{array}$ & $\begin{array}{c}\text { Energy } \\
\text { Billion kWH }\end{array}$ & $\begin{array}{c}\text { Capacity } \\
\text { (MW) }\end{array}$ & $\begin{array}{c}\text { Energy } \\
\text { Billion kWH }\end{array}$ & $\begin{array}{c}\text { Capacity } \\
\text { (MW) }\end{array}$ & $\begin{array}{c}\text { Energy } \\
\text { Billion kWH }\end{array}$ \\
\hline Geothermal & 1,790 & 13.4 & 5,100 & 40.2 & 3,310 & 26.8 \\
\hline Biomass & 697 & 5.8 & 2,000 & 15.8 & 1,303 & 10.0 \\
\hline Small Hydro & 830 est & 5.8 & 830 & 5.8 & 0 & 0 \\
\hline Wind & 2,655 & 4.9 & 12,700 & 33.4 & 10,045 & 28.5 \\
\hline Solar & 357 & 0.6 & 6,000 & 15.8 & 5,643 & 15.2 \\
\hline Total & 6,329 & 30.5 & 26,630 & 111 & 20,301 & 80.5 \\
\hline
\end{tabular}

Source: 2006 Capacity data from Energy Commission California Power Plant Database; 2006 energy data from Energy Commission 2006 Net System Power Report;. 2020 capacity data from Energy Commission Integrated Energy Policy Report 2007 Commission Final Report; Energy based on assumed capacity factors: $90 \%$ for geothermal and biomass; $30 \%$ for wind and solar.

Renewable energy and capacity requirements for 20\% and 33\% RPS scenarios in 2020, and 33\% and 50\% RPS scenarios in 2030 were calculated from the data in Table 4 and the results are presented in Tables 5 and 6 . The results presented are computed based on a simple ratio or scaling method, with some adjustment to account for the resource potential of each resource type, to estimate capacity and energy by resource type for different scenarios.

The renewable capacity and energy requirements for different scenarios presented in Tables 5 and 6 have been developed to quantify the approximate amount of renewable energy and capacity required. These approximations are meant to identify issues that need to be considered for renewables integration, including, for example, the need to expand deliverability capacity from transmission gateways to load centers. For the purposes of scoping operational integration issues, such an approximation is adequate.

Table 5. 2006 Renewable Capacity and Estimated Requirements in 2020 and 2030 (MW)

\begin{tabular}{|l|c|c|c|c|c|}
\hline & $\mathbf{2 0 0 6}$ & \multicolumn{2}{|c|}{$\mathbf{2 0 2 0}$} & \multicolumn{2}{c|}{$\mathbf{2 0 3 0}$} \\
\hline \multicolumn{1}{|c|}{ Resource Type } & Recorded & $\mathbf{2 0 \%}$ RPS & 33\% RPS & 33\% RPS & $\mathbf{5 0 \% ~ R P S ~}$ \\
\hline Geothermal & 1,790 & 3,091 & 5,100 & 5,100 & 7,725 \\
\hline Biomass & 697 & 1,212 & 2,000 & 2,000 & 3,031 \\
\hline Small Hydro & 830 est & 830 & 830 & 830 & 830 \\
\hline Wind & 2,655 & 7,697 & 12,700 & 15,084 & 24,561 \\
\hline Solar & 357 & 3,636 & 6,000 & 7,126 & 10,516 \\
\hline Total & 6,329 & 16,466 & 26,630 & 30,140 & 46,663 \\
\hline
\end{tabular}

Source: 2020 and 2030 capacity estimates scaled from 2020 33\% RPS values provided in Energy Commission Integrated Energy Policy Report 2007 Commission Final Report. 2030 capacity estimates 
for wind and solar based on 33\% capacity factor (assumed increased capacity factor due to improved technology by 2030)

Table 6. 2006 Renewable Energy \& Estimated Requirements in 2020 and 2030 (Billion kWH)

\begin{tabular}{|l|c|c|c|c|c|}
\hline & $\mathbf{2 0 0 6}$ & \multicolumn{2}{|c|}{ 2020 } & \multicolumn{2}{c|}{ 2030 } \\
\hline \multicolumn{1}{|c|}{ Resource Type } & Recorded & 20\% RPS & 33\% RPS & 33\% RPS & 50\% RPS \\
\hline Geothermal & 13.4 & 24.4 & 40.2 & 40.2 & 60.9 \\
\hline Biomass & 5.8 & 9.6 & 15.8 & 15.8 & 23.9 \\
\hline Small Hydro & 5.8 & 5.8 & 5.8 & 5.8 & 5.8 \\
\hline Wind & 4.9 & 20.2 & 33.4 & 43.6 & 71.0 \\
\hline Solar & 0.6 & 9.6 & 15.8 & 20.6 & 30.4 \\
\hline Total & 30.5 & 69.6 & 111 & 126 & 192 \\
\hline
\end{tabular}

Source: 2020 and 2030 energy estimates scaled from 2020 33\% RPS values in Table 4

From the analysis presented in Tables 5 and 6, the project team concluded that starting in 2006, renewable capacity additions of approximately 10,000 MW for the 20\% RPS and 20,000 MW for the $33 \%$ RPS will be needed by 2020. By 2030, capacity additions of 23,000 MW to 40,000 MW will be needed in order to attain the 33\% and 50\% RPS. Assuming that goals of 33\% RPS by 2020 and $50 \%$ RPS by 2030 must be met, the project team made the following observations starting from a 2006 base:

- Renewable capacity additions of 20,000 MW will be needed by 2020 and 40,000 MW will be needed by 2030 .

- Base load geothermal and biomass capacity will increase to 7,100 MW in 2020 and $10,700 \mathrm{MW}$ in 2030.

- Energy production from renewable resources will displace energy presently produced by non-renewable generation. By 2020, non-renewable generation will produce $13 \%$ less energy than in 2008.

- If renewables are non-dispatchable, then load following, regulation, ramping and other operational attributes to run the power system and meet the NERC's mandatory reliability standards will need to be provided by other resources and demand management.

- Intermittent wind energy will contribute about $10 \%$ of total energy requirements in 2020 and nearly $20 \%$ in 2030 .

\subsection{Renewables Development-Location and Resource Type}

For the purposes of identifying renewable resource integration issues, this analysis indicates that at least 30,000 MW of renewables will need to be integrated by the year 2030. The 30,000 MW represents a mid-range estimate from the 23,000 MW to 40,000 MW required to meet the scenarios of $33 \%$ and 50\% RPS goals, respectively, by 2030. Development of these renewables will be linked to the geographic regions these where resources are available. Based on a review 
of Energy Commission Renewable Energy Maps ${ }^{9}$ and the RETI Phase 1A Report ${ }^{10}$, renewables development is likely to be located as follows:

- Geothermal-Imperial Valley, Nevada, and Northern California.

- Biomass-Distributed within load centers.

- Wind-Tehachapi, Palm Springs, Imperial Valley, Northern California, NevadaArizona, Wyoming, and Pacific Northwest.

- Solar Photovoltaics-Distributed within load centers.

- Solar Thermal-Barstow, Mohave, and Central California

For this assessment, the location of renewables development is approximated based on data and studies sponsored by the Energy Commission and work currently under way by RETI. To meet the need for 30,000 MW of new renewable capacity, the Electric Power Group assumed the following scenario for development of new renewables:

- Geothermal-3,500 MW total, with 2,000 MW in Imperial Valley, $400 \mathrm{MW}$ in Northern California, $100 \mathrm{MW}$ in Randsburg (South of China Lake, Ca), and 1,000 MW in Northern Nevada.

- Biomass -1,500 MW distributed within or near load centers.

- Wind-16,000 MW total, with 6,000 MW in Tehachapi, 2,000 MW in Imperial Valley, 2,000 MW in San Gorgonio, 2,000 MW in Northern California, 2,000 MW from Pacific Northwest, and 2,000 MW from Nevada-Arizona.

- Solar Photovoltaic-2,000 MW distributed within load centers.

- Solar Thermal-7,000 MW total, with 2,500 MW at Mohave, 3,000 MW at Barstow, and $1,500 \mathrm{MW}$ in Central and Northern California.

Total production from the above resource additions and the currently installed capacity of renewable resources are shown in Table 7 below.

9. California Energy Commission Renewable Energy Maps, http://www.energy.ca.gov/maps/index.html 10. Renewable Energy Transmission Initiative Phase 1A Draft Report, March 2008, RETI-1000-2008-001-D 
Table 7. Resource additions and current installed capacity of renewable resources

\begin{tabular}{|l|c|c|c|c|}
\hline Resource Type & $\begin{array}{c}\text { 2006 Recorded } \\
\text { MW }\end{array}$ & Additional MW & $\begin{array}{c}\text { Total Resources } \\
\text { MW }\end{array}$ & $\begin{array}{c}\text { Annual Energy } \\
\text { Production BkWh }\end{array}$ \\
\hline Geothermal & 1,790 & 3,500 & 5,290 & 41.7 \\
\hline Biomass & 697 & 1,500 & 2,197 & 17.3 \\
\hline Small Hydro & 830 est & - & 830 & 5.8 \\
\hline Wind & 2,655 & 16,000 & 18,655 & 49.0 \\
\hline Solar Photovoltaic & - & 2,000 & 2,000 & 5.3 \\
\hline Solar Thermal & 357 & 7,000 & 7,357 & 19.3 \\
\hline Total & 6,329 & 30,000 & 36,329 & 138.4 \\
\hline
\end{tabular}

Sources: 2006 Recorded data from Table 4. New additions from estimates above. Annual energy production based on assumed capacity factors per Table 4

With the addition of 30,000 MW of new renewables to the recorded 2006 renewables capacity, the annual energy production from these resources was estimated to be $138.4 \mathrm{BkWh}$ based on a $30 \%$ capacity factor for wind and solar, and a $90 \%$ capacity factor for geothermal and biomass resources.

Based on forecast of total energy consumption of 383.1 BkWh for 2030, the renewable resource production based on Table 7 will be $36.1 \%$ of the 2030 energy requirement.

To understand the transmission and operating issues for integrating 30,000 MW of renewables, it is important to define what resources will be developed at what location. Table 8 below presents a hypothetical locational distribution of the renewable resources needed to meet the $33 \%$ energy requirement. This is merely one scenario formulated to identify the transmission and operating issues that will need to be considered. Table 8 is not meant to be a forecast, prediction, or recommendation of where renewables will or should develop.

Table 8. Hypothetical Amount (MW) and Location of Future Renewable Resources

\begin{tabular}{|c|c|c|c|c|c|c|c|c|c|c|c|c|}
\hline $\begin{array}{c}\text { Resource } \\
\text { Type }\end{array}$ & No. CA & $\begin{array}{c}\text { Central } \\
\text { CA }\end{array}$ & $\begin{array}{c}\text { Rands- } \\
\text { burg }\end{array}$ & $\begin{array}{l}\text { Teha- } \\
\text { chapi }\end{array}$ & $\begin{array}{c}\text { San Gor- } \\
\text { gonio }\end{array}$ & $\begin{array}{c}\text { Imperial } \\
\text { Valley }\end{array}$ & Mohave & $\begin{array}{c}\text { Bars- } \\
\text { tow }\end{array}$ & $\begin{array}{c}\text { Northern } \\
\text { Nevada }\end{array}$ & $\begin{array}{l}\text { Nevada- } \\
\text { Arizona }\end{array}$ & $\begin{array}{c}\text { Pacific } \\
\text { Northwest }\end{array}$ & Total \\
\hline Geothermal & 400 & & 100 & & & 2,000 & & & 1,000 & & & 3,500 \\
\hline Biomass* & & & & & & & & & & & & $1,500^{*}$ \\
\hline Wind & 2,000 & & & 6,000 & 2,000 & 2,000 & & & & 2,000 & 2,000 & 16,000 \\
\hline Solar PV* & & & & & & & & & & & & $2,000^{*}$ \\
\hline \begin{tabular}{|l|} 
Solar Thermal \\
\end{tabular} & & 1,500 & & & & & 2,500 & 3,000 & & & & 7,000 \\
\hline Total & 2,400 & 1,500 & 100 & 6,000 & 2,000 & 4,000 & 2,500 & 3,000 & 1,000 & 2,000 & 2,000 & 30,000 \\
\hline
\end{tabular}

* Assumed distributed within local load areas

\subsection{Transmission Gateways Around Load Centers and Capacity for New Renewables to be Delivered to Load Centers}

The integration of renewables into the power grid involves several elements:

- Interconnection with the grid-generally a radial line(s).

- Upgrades from the interconnection point to transmission gateways around load centers.

- Upgrades from transmission gateways to load centers for delivery of renewable power to loads. 
- Operation of the power system consistent with NERC and California ISO reliability standards and providing for needed regulation, ramping, operating reserve, voltage support, local resource adequacy, and other factors.

The California ISO annually performs studies to identify local load centers that are constrained by transmission. In the 2009 Local Capacity Technical Analysis ten load areas were identified for the 2008 forecast year, as summarized in Table 9.

Table 9. Peak Load Areas Identified in California ISO Study

\begin{tabular}{|l|c|c|}
\hline \multicolumn{1}{|c|}{ Local Area } & $\begin{array}{c}\text { 2008 Forecast Peak } \\
\text { Load (1 in 10) }\end{array}$ & $\begin{array}{c}\text { Percent of Total State } \\
\text { Load \% }\end{array}$ \\
\hline Humboldt & 199 & 0.4 \\
\hline North Coast/North Bay & 1,495 & 3.0 \\
\hline Sierra & 2,091 & 4.3 \\
\hline Stockton & 1,333 & 2.7 \\
\hline Greater Bay Area & 9,870 & 20.1 \\
\hline Greater Fresno & 3,260 & 6.6 \\
\hline Kern & 1,324 & 2.7 \\
\hline L.A. Basin & 19,648 & 40.0 \\
\hline Big Creek/Ventura & 4,911 & 10.0 \\
\hline San Diego & 4,992 & 10.2 \\
\hline Total & 49,123 & 100.0 \\
\hline
\end{tabular}

Source: California ISO 2009 Local Capacity Technical Analysis , Table 6

Based on the 2009 Local Capacity Technical Analysis, there are five local areas which comprise at least $5 \%$ of the total California ISO service area. These five areas total account for approximately $87 \%$ of the total California ISO load. The five areas are:

1. Greater Bay Area.

2. Greater Fresno Area.

3. L.A. Basin Area.

4. Big Creek/Ventura Area.

5. San Diego Area.

For each of the locally constrained resource areas, the transmission lines which form the study boundary and the gateway substations that bound each local area are identified. Based on the line ratings that bound each area, a total import capability can be determined for each of the load areas. The 2009 Local Capacity Technical Analysis describes the simultaneous import limits across the local area boundary transmission lines under the condition of the loss of the largest generating unit plus next most significant element (generator or line), which limit also affects the requirement for local operational generation. The aggregate import limits of the transmission gateways into each of the local areas are determined by subtracting the capacity of the largest generating unit within the local area from the locally constrained resource amount determined by the studies, then deducting that quantity from the local area load. This remainder represents the maximum aggregate import limit into the local area which can be 
safely scheduled while protecting the system against the loss of the largest generator within the local area plus the next most significant element, meeting the California ISO's Option 2 criteria $^{11}$, and is summarized in Table 10.

Table 10. Load Areas and Transmission Import Limits

\begin{tabular}{|l|c|c|}
\hline \multicolumn{1}{|c|}{ Load Area } & 2008 Load & $\begin{array}{c}\text { Aggregate Import Limit of Area } \\
\text { Transmission Gateways* }\end{array}$ \\
\hline Greater Bay Area & 9,870 & 5,995 \\
\hline Greater Fresno & 3,260 & 1,282 \\
\hline L.A. Basin & 19,648 & 10,642 \\
\hline Big Creek/Ventura & 4,911 & 2,028 \\
\hline San Diego & 4,992 & 2,500 \\
\hline
\end{tabular}

Source: California ISO. 2009 Local Capacity Technical Analysi, Table 6

In all instances, the actual rated capacity of all the transmission gateways to the load center was greater than the permissible aggregated import limit based on reliability and operating studies. For example, for the L.A. Basin Area served by California ISO, the aggregated rated capacity of all the gateways is over 23,000 MW but the aggregated import limit is less than half or 10,642 MW.

The L.A. Basin Area represents approximately $40 \%$ of the total California ISO load. As illustrated in Table 8, a significant portion of new renewables development is likely to interconnect and deliver power to transmission gateways surrounding the L.A. Basin Area. For example, wind resources in Tehachapi, Palm Springs, and Imperial Valley, and even Nevada and Arizona wind are likely to enter the California load centers through transmission gateways surrounding the L.A. Basin Area. The same is likely for geothermal resources in Imperial Valley and Nevada, and solar resources north of Lugo Substation (Barstow), and Vincent Substation (Mohave). Hence, for this scoping research assessment, the L.A. Basin Area was analyzed to assess issues that need to be considered for renewable resource integration. Similar transmission gateway issues can be expected at the grid's other major load areas as those areas increasingly depend on remotely sited renewable generation to provide their energy supply.

\footnotetext{
${ }^{11}$ California ISO. May 1, 2008. 2009 Local Capacity Technical Analysis Final Report and Study Results, page 15, [http://www.caiso.com/1fba/1fbace9b2d170.pdf]. "Option 2 is a service reliability level that reflects generation capacity that is needed to readjust the system to prepare for the loss of a second transmission element (N-1-1) using generation capacity after considering all reasonable and feasible operating solutions (including those involving customer load interruption) developed and approved by the CAISO, in consultation with the PTOs. Under this option, there is no expected load interruption to end-use customers under normal or single contingency conditions as the CAISO operators prepare for the second contingency. However, the customer load may be interrupted in the event the second contingency occurs."
} 


\subsection{Transmission Gateways Serving the Los Angeles Basin Area Served by the California ISO}

As discussed in Section 3.4, by 2030 the amount of capacity to be integrated ranges from 23,000 MW to 40,000 MW for 33\% and 50\% RPS, respectively. This assessment is based on a mid-range estimate of 30,000 MW that will have to be integrated over the next 20 years. Based on the estimates in Section 3.4 above, more than two-thirds of the new renewable resources would likely be delivered to L.A. Basin Area transmission gateways. This means that nearly 20,000 MW of new renewable capacity will have to be integrated via the L.A. Basin Area transmission gateways.

The current import limit of the L.A. Basin Area transmission gateways is approximately 10,000 MW. To accommodate an additional 20,000 MW of renewable generation that is likely to be developed or delivered into the Southern California region, the import limits at the L.A. Basin transmission gateways will have to increase by 20,000 MW.

The 20,000 MW of renewable resources to be developed will enter the L.A. Basin Area load centers through one or more of the transmission gateways listed in Table 11. Also see Figure 1, below.

Table 11. L.A. Basin Area Transmission Gateways for Integrating 20,000 MW of New Renewable Capacity

\begin{tabular}{|l|c|}
\hline \multicolumn{1}{|c|}{ Transmission Gateway } & Voltage (kV) \\
\hline San Diego - San Onofre & 230 \\
\hline Lugo - Mira Loma & 500 \\
\hline $\begin{array}{l}\text { Vincent - Mesa \& } \\
\text { Vincent - Rio Hondo }\end{array}$ & 230 \\
\hline Antelope - Mesa & 230 \\
\hline Palo Verde/Harquahala - Devers & 500 \\
\hline Coachella/Ramon - Mirage & 230 \\
\hline
\end{tabular}

Source: California ISO. 2008 Year Local Capacity Requirements Study. Big

Creek/Ventura Area and the L.A. BasinArea. ${ }^{12}$

12. California ISO. March 21, 2007. Year 2008 Local Capacity Requirements Study, Big Creek/Ventura Areas and Los Angeles Basin Areas Presentation, [http://www.caiso.com/1ba8/1ba87fb845160.pdf] . 


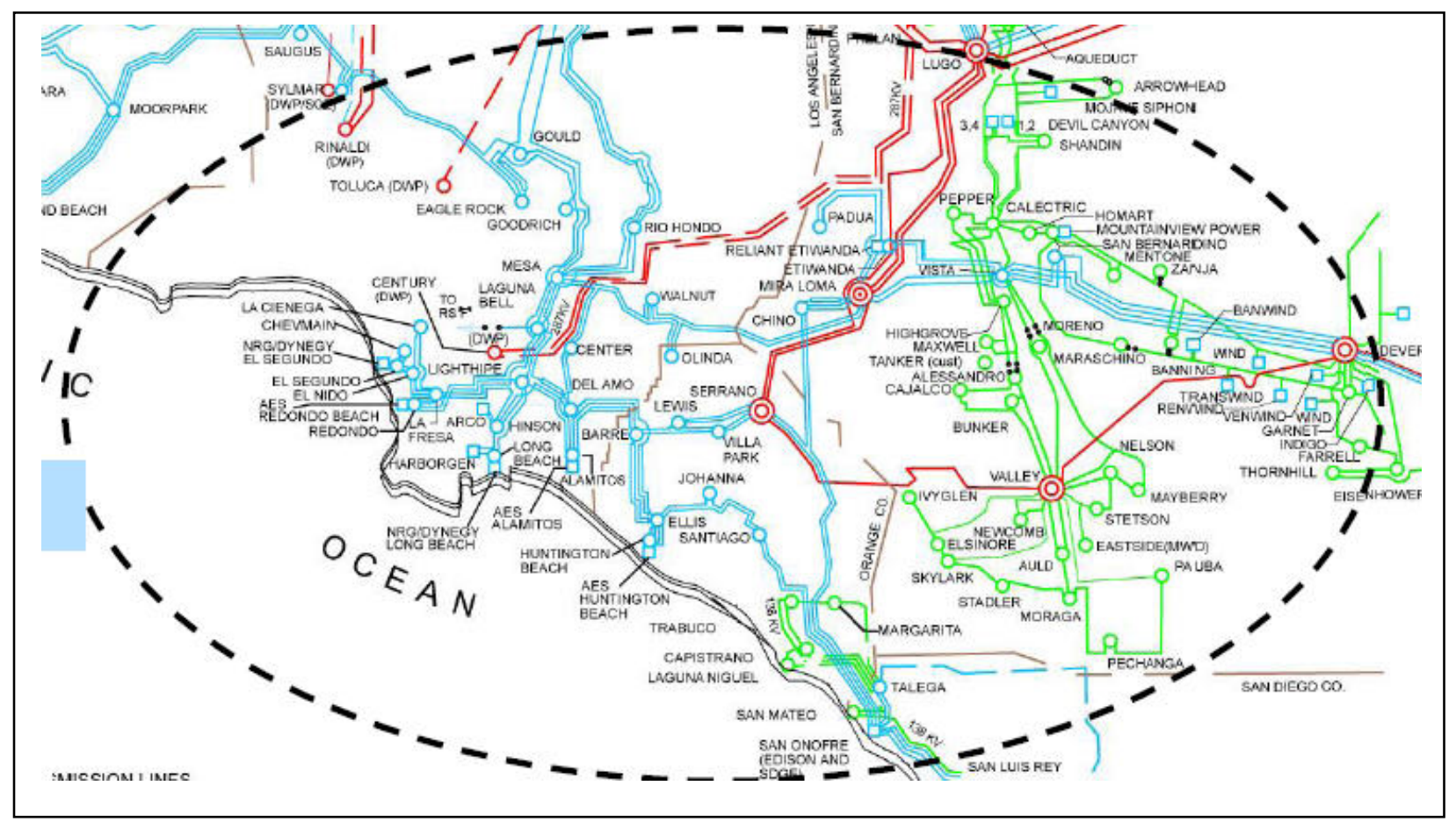

Figure 1. L.A. Basin Area Transmission Gateways

Source: California ISO. Local Capacity Requirements (LCR) for Year 2009 Study Results for the Big Creek/Ventura and L.A. Basin Areas.

Geothermal resources are likely to connect to Mirage (near Imperial Valley); wind at Devers, Antelope and Vincent; solar thermal at Lugo; and photovoltaics and biomass are likely to be distributed within the load centers.

\subsection{Transmission Gateway Capacity - Current Plans and Future Needs}

Current plans for expanding transmission serving the L.A. Basin Area include:

- $\quad$ Tehachapi, add 4,500 MW by 2012.

- Palo Verde/Harquahala-Devers No. 2, add 1,500 MW by 2013.

To accommodate the additional renewable generation from the locations identified in Table 8 above, the transmission gateways into the L.A. Basin Area will need to be expanded as illustrated below:

- Add 1,500 MW of capacity at Vincent/Antelope Gateway (wind).

- Add 4,000 MW of capacity at Mirage Gateway (geothermal and wind). 
- Add 5,500 - 7,500 MW of capacity at Lugo Gateway (solar thermal and Nevada-Arizona wind).

- Add 2,000 - 4,000 MW of capacity at Devers Transmission Gateway (wind).

The exact timing of when additional transmission is needed will depend on prioritizing which renewables are developed, where they are developed and the timing of the development. While the current focus is on renewables development and interconnections, planning for deliverability from transmission gateways to load centers needs to be initiated to prevent delays in integration of renewables. In addition, it will be necessary to expand the capacity for transfer of renewables from the L.A. Basin Area gateways to San Diego and Northern California.

\subsection{Transmission Expansion Required within Local Load Areas}

In addition to the transmission needed to deliver renewable generation to the grid, and the transmission needed to bring the generation from the grid through the gateway substations into the LCR areas, there are likely to be numerous other internal transmission reinforcements required to strengthen the local area grids. In an Energy Commission report study, the transmission system additions/modifications that would be required should certain amounts of aging power plant generation in the Southern California Edison (SCE) area be retired were discussed. ${ }^{13}$ While the premise of the study was the retirement of aging power plants in the SCE area, the results are generally applicable to the scenario of increased use of renewable generation with an attendant reduction in the use of existing aging power plants (even if the aging power plants are assumed to remain operable). The study identified several transmission lines within the SCE system that would need to be upgraded to accommodate additional generation deliveries from the eastern portion of the SCE grid (the location of the bulk of the concentrated solar and geothermal resources), including:

- Chino-Mira Loma \#1 $230 \mathrm{kV}$ line upgraded.

- Pardee-Moorpark \#2 and \#3 $230 \mathrm{kV}$ lines upgraded.

- Chino-Mira Loma \#3 $230 \mathrm{kV}$ line reconductored.

- Barre-Ellis $230 \mathrm{kV}$ line reconductored.

- La Fresa-Redondo \#1 and \#2 lines reconductored.

- Serrano-Villa Park \#1 and \#2 reconductored.

- Both Pisgah-Lugo $230 \mathrm{kV}$ lines reconductored.

- Antelope-Pardee $230 \mathrm{kV}$ line converted to $500 \mathrm{kV}$ operation.

- Vincent-Santa Clara $230 \mathrm{kV}$ line is looped into Pardee, and the Vincent-Pardee section is converted to $500 \mathrm{kV}$ operation.

13. California Energy Commission, A Scenario Analyses of California's Electricity System: Preliminary Results for the 2007 Integrated Energy Policy Report, Second Addendum Draft Report, August 2007, CEC-200-010-AD2-AP. 
- 500 MVAR of reactive support is installed at various substations in the L.A. Basin and Ventura County.

- Series capacitors in the Eldorado-Lugo $500 \mathrm{kV}$ line is upgraded.

- The Tehachapi Renewable Transmission Project is completed.

- The Palo Verde/Harquahala-Devers No. $2500 \mathrm{kV}$ line is completed.

The estimated cost of the upgrades required to accommodate the shifted generation priority (eastern renewable generation in favor of local aged gas-fired generation), expansion of transmission gateway capacity, and the cost of expanded interconnections such as the Tehachapi Renewable Transmission Project and the Palo Verde/Harquahala-Devers No. 2 $500 \mathrm{kV}$ line will be substantial. The Tehachapi transmission upgrades are estimated to cost $\$ 1.8$ billion for integrating 4,500 MW of wind or approximately $\$ 400 / \mathrm{kW}$. The cost of integrating 20,000 MW of new renewables, assuming the same order of magnitude as Tehachapi, translates to approximately $\$ 8$ billion. This requires substantial commitment to plan and implement the needed transmission upgrades for integration of renewables in a timely manner.

While this project team has not yet performed similar assessments for the other local areas, the team expects that significant transmission upgrades will be required in the other local areas in order to accommodate greater dependence on imported (from outside the local area) renewable generation.

While some local area transmission upgrades will certainly be required to accommodate local load growth and increased reliance on generation external to the local area (delivered through the gateway substations and transmission lines), initiatives that accelerate the dependence on external generation, such as programmatic shutdown of coastal generation (for example, U.S. Clean Water Act Section 316(b) requires a mandatory reduction in the use of once-through cooling), or requirements to shift generation from gas-fired sources to renewable sources at rates higher than load growth, will accelerate the need for local transmission upgrades, and incur costs such as those identified in the staff study. 


\subsection{Operational Integration Issues}

\subsection{Issues to Be Considered for Renewable Resource Integration}

Currently, the California ISO experiences many operational issues such as regulation, ramping, voltage support with the existing resource portfolio in its control area, and these issues will likely worsen with addition of remote renewables and shutdown of local generation due to air quality and water use constraints, unless steps are taken to resolve or mitigate the issues. Most of the issues relate to resource and demand balancing within the control area. According to NERC Standards BAL-001 and BAL-002, the control area's performance shall be in support of "maintaining the Interconnection steady-state frequency within defined limits by balancing real power demand and supply in real-time and to utilize its contingency reserve to balance resources and demand and return Interconnection frequency within defined limits following a reportable disturbance." 14 Besides the fact that the operational issues can be extremely challenging for the control area operator to manage, the failure to comply with a NERC Standard could lead to a $\$ 1$ million/per day penalty.

There are four drivers that will accelerate the displacement of the existing fleet of relatively flexible power plants with a replacement fleet of renewables and non-renewable resources with no or very limited operating attributes, which will compound the existing operational issues. The four drivers are:

- Integration of intermittent and non-dispatchable renewables.

- Plant aging and efficiency.

- U.S. Clean Water Act Section 316(b) - mandatory reduction in the use of once-through cooling, which could lead to plant closures that cannot or will not comply.

- California Assembly Bill 32-targets greenhouse gas reduction.

Operational issues are discussed below.

a. Existing Local Generation-Local capacity resources provide much of the needed regulation, ramping, load following, voltage support and inertia for reliable power system operation. If a significant portion of the existing local generation is shut down, regulation, load following and ramping would have to be provided through other means. Future control area resource attribute requirements need to be defined such that the utilities are procuring the resources with the necessary attributes.

b. Voltage support-The existing fleet of power plants provide some of the much-needed voltage support in the local load centers. When this fleet is retired or not operating, the transmission grid will require additional transmission investment in hardware such as capacitors and other more sophisticated dynamic voltage support devices.

14. NERC Standard BAL-001-0,Requirement 1 and 2, Standard BAL-002-0, Requirement 4, [http://www.nerc.com/ filez/standards/Reliability Standards Regulatory Approved.html]. 
c. Inertia-Inertia is the energy stored in large spinning machines (for example, a generator) that supplies the stored energy during periods of system disturbance (for example, loss of a generator) to arrest the rate at which the system frequency changes. Different types of generation technology provide different levels of inertia. For example, wind provides a low level of inertia compared to a conventional fossil fuel generator. As the electric industry shows a greater dependency on renewable resources and the existing fleet of generating resources is either retired or utilized less, there will be a negative impact on the dynamic response of the California grid, as well as the Western Interconnection. As a result of a reduction in the inertia connected to the grid the Southern California Import Transmission (SCIT) nomogram capacity will be reduced and additional transmission will be needed to make up for such reduction. It is important that inertia requirements are defined in the California resource procurement process.

d. Minimum Load - When total off-peak power production (after reducing controllable generation to minimum levels) exceeds loads, the situation is referred to as a minimum load issue. High levels of off-peak production (for example, from base load, existing contracts, hydro runoff/run of the river and intermittent energy resources) pose operating challenges for the control area operator, the transmission operator, and the energy supplier, and may require generation curtailment, reduction in imports, increase in off-peak sales, or increase in off-peak loads (pumped storage or retail customer load). Currently, the California ISO is challenged during the spring run-off period and a few other times of the year with minimum load issues. The situation will only worsen as additional base load (for example, geothermal) and intermittent resources are connected to the grid. Currently, California has in excess of 4,000 MW of pumped storage capability that, if coordinated, could be used to mitigate this issue. Also new pumped storage facilities could be constructed. The State should ensure that coordination agreements are developed between owners of pumped storage facilities or encourage the construction of new storage facilities.

e. Renewable Resource Mix - As mentioned in the beginning of this report, SB 1078 established a statewide RPS of $20 \%$ by 2017, which in 2006 was accelerated to $20 \%$ RPS by 2010. In addition, the CPUC and Energy Commission, in their Energy Action Plan II, called for renewable resources to provide 33\% of California's electricity by $2020 .{ }^{15}$ There is a need to define the needed operating attributes that can be met by use of the different resource technologies such that the system remains operable under all expected conditions, such as minimum load conditions, system disturbances, and rapid demand or resource changes.

15. Energy Commission and California Public Utilities Commission. September 21, 2005. Energy Action Plan II, [http://www.energy.ca.gov/energy action plan/2005-09-21 EAP2 FINAL.PDF]. 
The 2007 Intermittency Analysis Project (IAP) final report ${ }^{16}$ concluded:

"California can incorporate the amount of renewables based on the Intermittency Analysis Project scenarios, provided appropriate infrastructure, technology, and policies are in place.

Specifically, this successful integration will require:

o Investment in transmission, generation, and operations infrastructure to support the renewable additions.

o Appropriate changes in operations practice, policy and market structure.

o Cooperation among all participants, for example, the California Independent System Operator, investor-owned utilities, renewable generation developers and owners, Non-Federal Energy Regulatory Commission jurisdictional power suppliers, and regulatory bodies."

The state should ensure that the action items identified in the IAP report are addressed.

f. Demand Management, Dynamic Pricing, Storage, and Automatic Load Control-As California continues to transition into the implementation phase of RPS and a greater portion of consumers' energy demand is met with renewable resources, we may find that the available resource mix is unable to meet the NERC generation and load balance standards. In anticipation of this potential problem, the State needs to explore options to enhance the use of load for demand management (peak shaving for lack of quick start resources), dynamic pricing, storage, and automatic load control (ALC) to provide certain control area attributes (for example, ramping and regulation).

16. Energy Commission. July 2007. 2007 Intermittency Analysis Project: Final Report, Publication Number CEC-500-2007-081, [http://www.energy.ca.gov/2007publications/CEC-500-2007-081/CEC-500-2007081.PDF]. 


\subsection{Conclusions and Recommendations}

\subsection{Conclusions}

\subsubsection{California's renewable resource needs and locations}

Assuming that goals of 33\% RPS by 2020 and 50\% RPS by 2030 must be met, the project team made the following key observations starting from a 2006 base:

- Renewable capacity additions of 20,000 MW will be needed by 2020 .

- Approximately 47,000 MW of renewable capacity will be needed by 2030.

- For 33\% and 50\% Renewable Portfolio Standard scenarios for 2030, new renewable capacity of 23,000 to $40,000 \mathrm{MW}$ will be needed, or a mid-range value of 30,000 MW over the next 20-years.

- More than two-thirds of the new renewable resources would likely be delivered to L.A. Basin Area transmission gateways. This means that nearly 20,000 MW of new renewable capacity will have to be integrated via the L.A. Basin Area transmission gateways.

\subsubsection{Transmission gateways and access to load centers}

Renewables resources have to be interconnected to the power grid for eventual delivery of power to the load centers. The integration of renewables into the power grid involves several elements:

- Interconnection with the grid-generally a radial line(s).

- Upgrades from the interconnection point to transmission gateways around load centers.

- Upgrades from transmission gateways to load centers for delivery of renewable power to loads.

\subsubsection{Integration of remote non-renewable resources}

The need for integration and transmission upgrades discussed in this report only addresses the needs related to renewable resources. It is very likely that some of the non-renewable resources that will be required to meet the State's increasing load demand, plant retirements and to provide operating flexibility may be located outside the local load centers. The transmission requirements to integrate these non-renewable resource requirements will be in addition to what has been discussed in this report.

\subsubsection{Operational issues}

Currently, the California ISO experiences many operational issues with the existing resource portfolio in its control area. Most of the issues are related to resource and demand balancing within the control area, such as over-generation during minimum load conditions, system disturbances (loss of generation), and rapid demand or resource changes. Poor operating performance could lead to non-compliance with NERC's mandatory standards, which could lead to a $\$ 1$ million/per day penalty. As mentioned earlier, there are four drivers that will accelerate the displacement of the existing fleet of relatively flexible power plants with a 
replacement fleet of renewables and non-renewable resources with no or somewhat limited operating attributes, which will compound the existing operational issues.

\subsubsection{Planning and operating issues}

Many of the planning and operating issues can be addressed by choice of resource mix and public policy. A summary qualitative assessment of resource options and their impacts on renewable resource integration is outlined in Table 12.

Table 12. Qualitative Assessment of Resource Options on Renewables Integration

\begin{tabular}{|l|r|}
\hline \multicolumn{1}{|c|}{ Resource Option } & \multicolumn{1}{c|}{ Assessment } \\
\hline Distributed Photovoltaic & Reduces transmission and ramping needs \\
\hline Distributed Biomass & Reduces transmission needs \\
\hline $\begin{array}{l}\text { Demand management, dynamic } \\
\text { pricing }\end{array}$ & Reduces transmission, regulation and ramping needs \\
\hline Storage & Provides ramping, regulation, and quick response for reliability management \\
\hline Solar Thermal & Provides ramping and regulation coincident with load ramps \\
\hline $\begin{array}{l}\text { Peaking Capacity—distributed } \\
\text { within load centers }\end{array}$ & $\begin{array}{r}\text { Reduces need to expand transmission gateway capacity. Provides ramping, } \\
\text { regulation, and quick response for reliability management }\end{array}$ \\
\hline Shut down of local generation & \begin{tabular}{l} 
Increases need for transmission gateway capacity, regulation, and ramping \\
\hline
\end{tabular}
\end{tabular}

Table 13 provides a qualitative assessment of issues and the necessary action items to effectively integrate renewables and ensure reliable power system operations.

Table 13. Qualitative Assessment of Issues and Action Items for Renewables Integration

\begin{tabular}{|l|c|}
\hline \multicolumn{1}{|c|}{ Issues } & Action Items \\
\hline Add New Renewables & Addition of 20,000 MW of Renewables-Base Case \\
\hline $\begin{array}{l}\text { Transmission Gateway } \\
\text { Capacity }\end{array}$ & $\begin{array}{c}\text { Expand by 10,000 to 20,000 MW } \\
5-15 \text { year lead time }\end{array}$ \\
\hline $\begin{array}{l}\text { Local Network } \\
\text { Reinforcements }\end{array}$ & Epgrade lines, fault current limiters, breakers, remedial action schemes \\
\hline $\begin{array}{l}\text { Nomogram Capacity } \\
\text { Import Limits }\end{array}$ & Expand by 10,000 to 20,000 MW \\
\hline Regulation and Ramping & Need additional Regulation \& Ramping \\
\hline Local Voltage Support & Utilize storage, demand management, automatic load control \\
\hline
\end{tabular}




\subsection{Recommendations}

Meeting California's RPS on a timely basis requires a concerted effort on several fronts:

a. The planning and study focus needs to immediately expand from evaluating just the interconnection of remote renewable resources to the grid to one of delivering the renewable energy all the way to the respective load centers.

b. Policy makers need to provide guidance on resource type and location to facilitate timely integration of renewables, and support early planning and upgrades of transmission gateway capacity and deliverability to load centers. This effort will be aided by the RETI effort currently underway.

c. Transmission owners and California ISO need to move the planning horizon out to 1520 years.

o Define long-term transmission gateway requirements.

o Define long-term transmission requirements from the gateways into the load centers.

d. Transmission owners and California ISO need to initiate studies (similar those conducted for Tehachapi) to expand transmission gateways and beyond into the load centers.

e. Provide policy makers with information associated with the complete transmission integration requirement and cost implications for delivering all remote resource (renewable and non-renewable) to the local load centers.

f. California ISO needs to provide utilities and CPUC with guidance on resource attributes needed for reliable operation of the power system.

g. Review transmission requirements for transfer of renewable energy from the L.A. Basin Area to San Diego and Northern California. 


\subsection{Benefits to California}

Carrying out the recommendations from this initial scoping research study will facilitate integration of renewables to meet California's goals for greater utilization of renewable resources and meeting the RPS. 


\subsection{References}

Black \& Veatch. April 2008. Renewable Energy Transmission Initiative. Phase 1A Draft Report, Black \& Veatch Project: 149148. Energy Commission Publication Number: RETI-1000-2008-001D, [http://www.energy.ca.gov/2008publications/RETI-1000-2008-002/RETI-1000-2008-002D.PDF].

California Energy Commission. April, 2007. 2006 Net System Power Report, CEC-300-2007-007.

California Energy Commission. November 2007. California Energy Demand 2008 - 2018: Staff

Revised Forecast - Final Staff Report, 2nd Edition. [www.energy.ca.gov/2007publications/CEC-2002007-015/CEC-200-2007-015-SF2.PDF].

California Energy Commission. May 30, 2008. California Power Plant Database, [http://www.energy.ca.gov/database/sitingcase/alphabetical.html].

California Energy Commission. Geothermal Resource Areas Map, [http://www.energy.ca.gov/maps/geothermal areas.html] .

California Energy Commission. December 5, 2007. Integrated Energy Policy Report, 2007 Summary, Commission Final Report, CEC-100-2007-008-CMF-ES.

California Energy Commission. Map of Solar Resource Potential in California, [http://www.energy.ca.gov/maps/solar_potential.html].

California Energy Commission. August 2007. Scenario Analysis of California's Electricity System: Preliminary Results for the 2007 Integrated Energy Policy Report, Addendum 2, Appendices, CEC-2002007-010-AD2-AP.

California Energy Commission. Wind Resource Map, [http://www.energy.ca.gov/maps/wind.html].

California Energy Commission. December 5, 2007. Integrated Energy Policy Report, 2007 Summary, Commission Final Report, CEC-100-2007-008-CMF,

[http://www.energy.ca.gov/2007publications/CEC-100-2007-008/CEC-100-2007-008-CMF.PDF].

California Independent System Operator. April 10, 2008. Local Capacity Requirements (LCR) for Year 2009 - Study Results for the Big Creek/Ventura and LA Basin Areas,

[http://www.caiso.com/1f9d/1f9d890a196a0.pdf].

California Independent System Operator. Year 2008 LCR Study, San Diego Area, Summary of Findings, [http://www.caiso.com/1ba8/1ba87f5042ad0.pdf].

California Independent System Operator. March 9, 2007. 2008 Local Capacity Technical Analysis Report and Study Results, [http://www.caiso.com/1b9c/1b9cd9a225830.pdf].

California Independent System Operator. May 1, 2008. 2009 Local Capacity Technical Analysis Final Report and Study Results, [http://www.caiso.com/1fba/1fbace9b2d170.pdf ]. 
California Independent System Operator. Operating Procedures,

[http://www.caiso.com/thegrid/operations/opsdoc/index.html].

California Independent System Operator. March 12, 2007. Year 2008 Local Capacity Requirements Study, Big Creek/Ventura Area and the LA Basin Area,

[http://www.caiso.com/1ba8/1ba87fb845160.pdf].

California Independent System Operator. Year 2008 Local Capacity Requirements (LCR), Greater Fresno and Kern Areas, [http://www.caiso.com/1ba8/1ba87ff44e2c0.pdf].

California Independent System Operator. Year 2008 Local Capacity Requirements Study, Greater Bay Area, Summary of Findings, [http://www.caiso.com/1ba8/1ba8802c4fcf0.pdf].

North American Electric Reliability Corporation (NERC). Standard BAL-001-0 and Standard BAL-002-0,

[http://www.nerc.com/ filez/standards/Reliability Standards Regulatory Approved.html]. 


\subsection{Glossary}

$\begin{array}{ll}\text { ALC } & \text { Automatic Load Control } \\ \text { California ISO } & \text { California Independent System Operator } \\ \text { CPUC } & \text { California Public Utility Commission } \\ \text { CREZ } & \text { Competitive Renewable Energy Zones } \\ \text { Energy Commission } & \text { California Energy Commission } \\ \text { GHG } & \text { Greenhouse Gas } \\ \text { IAP } & \text { Intermittency Analysis Project } \\ \text { L.A. } & \text { Los Angeles } \\ \text { LCR } & \text { Locally Constrained Resource } \\ \text { MW } & \text { Megawatts } \\ \text { NERC } & \text { North American Electric Reliability Corporation } \\ \text { PIER } & \text { Public Interest Energy Research } \\ \text { RETI } & \text { Renewable Energy Transmission Initiative } \\ \text { RPS } & \text { Renewable Portfolio Standard } \\ \text { SCE } & \text { Southern California Edison } \\ \text { SCIT } & \text { Southern California Import Transmission } \\ \text { U.S. EPA } & \text { United States Environmental Protection Agency } \\ & \end{array}$

